\title{
CD99 Antigen
}

National Cancer Institute

\section{Source}

National Cancer Institute. CD99 Antigen. NCI Thesaurus. Code C102941.

CD99 antigen (185 aa, $19 \mathrm{kDa}$ ) is encoded by the human CD99 gene. This protein plays a role in cell adhesion. 